\title{
Developing writing skills of learners with persistent literacy difficulties through the explicit teaching of grammar in context
}

McCormack-Colbert, Anna; Ware, Jean; Jones, Susan

\section{Support for Learning}

\author{
DOI: \\ 10.1111/1467-9604.12200
}

Published: 01/01/2018

Peer reviewed version

Cyswllt i'r cyhoeddiad / Link to publication

Dyfyniad o'r fersiwn a gyhoeddwyd / Citation for published version (APA):

McCormack-Colbert, A., Ware, J., \& Jones, S. (2018). Developing writing skills of learners with persistent literacy difficulties through the explicit teaching of grammar in context. Support for Learning, 33(2), 165-189. https://doi.org/10.1111/1467-9604.12200

\footnotetext{
Hawliau Cyffredinol / General rights

Copyright and moral rights for the publications made accessible in the public portal are retained by the authors and/or other copyright owners and it is a condition of accessing publications that users recognise and abide by the legal requirements associated with these rights. study or research.

- Users may download and print one copy of any publication from the public portal for the purpose of private

- You may not further distribute the material or use it for any profit-making activity or commercial gain

- You may freely distribute the URL identifying the publication in the public portal ?
}

Take down policy

If you believe that this document breaches copyright please contact us providing details, and we will remove access to the work immediately and investigate your claim. 


\section{Developing writing skills of learners with persistent literacy difficulties through explicit grammar teaching}

\section{Introduction}

\section{Background}

The benefits of grammar instruction in the teaching of writing are contested in most English-speaking countries (Jones et al. 2013). A majority of Anglophone countries abandoned the teaching of grammar in the 1950s based on the conclusions that it had no positive impact on learners' development of reading, writing and language (Locke, 2005).

Nevertheless, in England (Department for Education, 2014) and Wales (Welsh Government, 2016), grammatical writing accuracy is an expectation set by the Government from Key Stage 1 onwards. Despite the emerging expectation that learners understand grammatical metalanguage, there is no coherent reasoning for the inclusion of grammar instruction in the English Programmes of Study in England and in Wales (Myhill et al. 2018). 
According to Mellanby \& Theobald (2014), being aware of grammatical structures can help learners develop their reading comprehension skills. Although British learners are generally not taught grammar rules explicitly, 'children in schools in France, the Netherlands, Germany and many other European countries are taught explicitly about the structure of their language' (Mellanby \& Theobald, 2014, p65). Mellanby \& Theobald highlight that exposing learners to grammatical analysis in an interesting context could help learners develop their understanding of language.

Myhill et al.'s (2012) study provides evidence that, although the decontextualised teaching of grammar is not helpful in improving writing, a 'writing curriculum which draws attention to the grammar of writing in an embedded and purposeful way at relevant points in the learning' (p32) helps learners develop their understanding of the mechanisms of language.

McCormack-Colbert et al. (2017) carried out a study which aimed at gaining an appreciation of the experience of learners assessed as having dyslexic tendencies in the French and Welsh comprehensive school systems. French participants in the study made comments which support Myhill et al.'s findings. French learners mentioned they found the teaching 
of grammatical concepts helpful. They said that it gave them a better understanding of language as it provided scaffolding when they had to produce extended pieces of writing. Participants felt that they could not memorise how to spell words but found the structure provided by the teaching of grammar rules very useful. Each part of speech has an identified role in the sentence. This means that rather than have to memorise lists of words or spelling patterns, they can focus on determining each word or phrase's task in the sentence. These processes of categorisation and deduction are higher order thinking skills.

When considering definitions of dyslexia available in the United Kingdom, participants' comments are very insightful. The British Psychological Society (2005) define dyslexia as a persistent literacy difficulty which affects reading fluency and spelling. Nevertheless, Rose and the BDA (2009) mentioned that learners with dyslexia often develop strengths in problem solving; the teaching of grammar could therefore help them develop their understanding of language by using problem solving skills (Myhill et al. 2012). 


\section{Aims}

This action research study aims at gaining a further understanding of how the explicit teaching of grammar in context can benefit learners with persistent literacy difficulties. The project is designed to identify ways of adapting the Grammar for Writing materials (Myhill, 2013) so that learners with specific learning differences such as dyslexia can access them.

\section{Theoretical overview}

\section{Dyslexia and writing skills}

\section{a/ Dyslexia: definition and literacy intervention}

Defining such a complex learning difference as dyslexia is a challenge. It is agreed that the definition should refer to difficulties reading text but 'the field has been unable to produce a universally accepted definition that is not imprecise, amorphous, or difficult to operationalize' (Elliott \& Grigorenko, 2014, p5). The fact that no two cases of dyslexia present exactly the same characteristics (Reid, 2011, p16) leads to even more confusion. There is thus no unique and empirical definition, rather a plethora of them. 
In Wales, nineteen of the twenty-two LAs (WG, 2012, p17) refer to the definition of dyslexia adopted by the British Psychological Society. This definition was agreed in 1999 but was updated in 2005:

'Dyslexia is evident when accurate and fluent word reading and/or spelling develops very incompletely or with great difficulty. This focuses on literacy learning at the 'word level' and implies that the problem is severe and persistent despite appropriate learning opportunities. It provides the basis for a staged process of assessment through teaching' (British Psychological Society, 1999 updated 2005, p 20).

This definition refers to the issues that learners with dyslexia encounter in terms of reading and spelling but does not refer to the development of higher order reading or writing skills.

According to Elliott \& Grigorenko (2014), many studies have stressed the benefits of phonics-based interventions to help learners with dyslexia overcome their difficulties. However, there is evidence that the use of phonics tends to have little impact on older learners with literacy difficulties (Flyn et al. 2012). 
Halliday (2014) states that the sound system (phonemes) and the writing system (graphemes) of a language are the two modes of expression by which the 'lexicogrammar' (p7) of a language is represented:

'There is another level of organization in language to which both the sound system and the writing system are related, namely the level of wording, or lexicogrammar' (Halliday, 2014, p7).

Lexicogrammar is a level of linguistic structure where vocabulary and grammar, or syntax, combine into one. Words and grammatical structures are not seen as independent, but rather as mutually dependent. Learners with dyslexia should be encouraged to make connections between these two systems (sound and writing) so that they can then develop higher order literacy skills such as inferential reading comprehension skills as it should help them improve their writing technique (Moreau, 2015). Approaches solely based on phonics do not enable learners to make necessary connections between word semantics and grammatical structures. Older learners need to be given the opportunity and necessary support to develop their higher order reading and writing skills in order to cope with the demands of GCSE, AS and A Level examinations. 


\section{b/ Dyslexia: spelling and composition}

Spelling is a prerequisite to expressing vocabulary in writing (Sumner et al. 2016). It is consistently reported that learners with persistent literacy difficulties such as dyslexia cannot spell accurately (BPS, 2005; Ramus, Marshall, Rosen, \& van der Lely, 2013), and generally struggle with the composition of written texts (Berninger et al. 2008; Connelly et al. 2006; Gregg et al. 2007; Sumner et al. 2014).

In addition, the cognitive demand of spelling directly affects the amount of time that writing takes for learners with dyslexic tendencies and is linked to the quality of writing produced (Sumner et al. 2016). According to Sumner et al., little research has focused on the writing produced by primary and secondary school learners. However, the existing literature suggests that learners with dyslexic tendencies avoid writing words they cannot spell (Berninger et al., 2008), which implies that the breadth of vocabulary used is restricted.

According to Morken \& Helland (2013), dyslexia research has mainly focused on reading. Less attention has been given to writing, especially at the sentence and text levels. Considering indications that problems with writing often persist even after receiving reading intervention (Berninger, 
2006), gaining a better understanding of the nature of the writing problems associated with dyslexia is of great importance to facilitate effective literacy teaching.

\section{Grammar in the curriculum}

The place of grammar teaching in the English or Welsh curriculum has long been a source of debate (Myhill et al. 2012). Grammar teaching is often associated to notions of correctness and standards.

\section{a/ Theoretical perspective on the teaching of grammar}

In most English-speaking countries, the rigid grammar exercises of the 1950s were abandoned in the 1960s because of a loss of confidence in the benefits of grammar teaching. In particular, it was felt that the grammar being taught was a body of abstract linguistic concepts which did not help learners develop reading and writing skills (Myhill \& Watson, 2014).

In non-Anglophone countries like France, grammar is heavily drawn upon in order to develop learners' understanding of French spelling (McCormack-Colbert et al. 2017) and mechanisms of language. 
According to Myhill \& Watson (2014), when the relevance of explicit and implicit grammatical knowledge is challenged, one strong focus of the debate is underpinned by discussions around the impact of teaching grammar on students' language use, particularly writing.

\section{b/ The effects of contextualised grammar teaching on learners' writing}

Studies repeatedly concluded that decontextualised grammar teaching is not helpful in improving writing skills. Myhill et al.'s study (2012) aims at demonstrating that 'a writing curriculum which draws attention to the grammar of writing in an embedded and purposeful way at relevant points in the learning is a more positive way forward' (p3). When grammar teaching is contextualised, learners are introduced to what Myhill et al. have called 'a repertoire of infinite possibilities' (2012, p3). The aim of the explicit grammar teaching in context approach is to help learners take control and to make informed choices when they are producing a piece of writing.

However, Jones et al.'s (2012) findings indicate that the approach only benefited learners whose baseline assessment scores in writing were above average. The impact of the intervention was minimal on learners 
whose baseline writing attainment was below average. This strongly suggests that the Grammar for Writing pedagogy may have been particularly well-matched to the learning profiles of more able writers (Jones et al. 2012).

\section{Methodology}

\section{a/ Research approach}

This project uses a mixed method approach. The data collection tools used were standardised test data, teacher assessment data, semistructured interviews, archival records, documentary data and one lesson observation. As this research project is mainly concerned with understanding phenomena 'from within' (Cohen et al. 2007, p21), it was sensible to adopt an interpretative approach. The interpretative approach leads to an in-depth understanding of the particular but also contributes to building a framework of 'multiple realities' (Thomas, 2009, p78). In addition, the interpretative or naturalistic paradigm is underpinned by a concern for individuals. The researchers hope to 'retain the integrity of the phenomena being investigated' (Cohen et al. 2007, p21) by gaining an insight into the participants' experiences. 


\section{b/ Project design, research setting and participants}

This project is a follow-up study based on findings from a Doctorate in Education thesis suggesting that French participants found the teaching of grammar useful. This research project is designed to identify what adaptations need to be made to Myhill's Skills for Writing (2013) materials in order for them to be useful in helping learners with persistent literacy difficulties develop their writing skills.

It intends to improve educational practice (Koshy, 2010) through action, analysis and reflection. The researchers aim at transforming the approach to supporting learners with persistent literacy difficulties by 'transforming the quality of the teaching-related activities' (Koshy, 2010, p1). The project, therefore, uses an action research design and the objective of this article is to outline and discuss findings from the first cycle of the study.

The lead researcher collected the sets of data in a comprehensive secondary school setting in Wales. The school welcomes learners from age 11 to 18 and there are $21.9 \%$ of learners on the Additional Learning Needs register. The learners participating in the study were all in year 9 . Following a routine analysis of reading comprehension standardised test 
data, the Additional Learning Needs Coordinator placed them on a literacy support intervention.

The first cycle of this action research project involves 9 participants:

- 5 learners who have been identified as needing additional literacy support using the school's criteria for intervention.

- 1 specialist teacher.

- 2 teachers.

- $1 \mathrm{ALNCO} /$ lead researcher.

The learners used the Skills for Writing materials as part of literacy intervention classroom routine.

The following figure illustrates the model adopted by the researchers. This spiral model should enable us to progress towards a greater understanding of what adaptations need to be made so that learners can benefit from Myhill's explicit grammar teaching approach. 


\section{Plan}

\section{Reflect}

Cycle 1

Teach

\section{Plan}

\section{Reflect}

Cycle 2

\section{Teach}

Figure 1 - Adapted from Kemmis \& McTaggart (2005, p 278)

The first research cycle enabled the researchers to gain an understanding of the changes needed by working with and consulting the participants. The researchers are therefore able to make 'informed decisions through enhanced understanding' (Koshy, 2010, p5). 


\section{Ethical considerations}

The British Educational Research Association Revised Ethical Guidelines for Educational Research state that:

'The Association takes voluntary informed consent to be the condition in which participants understand and agree to their participation without any duress, prior to the research getting underway' (2011, p5).

The lead researcher provided participants with information sheets and consent forms. The information sheets include all information that participants need to know, such as the nature and purpose of the study, the expected benefits of the study but also the possible harm that may come from the study as well as information about confidentiality and anonymity. The potential participants were also given the choice to take part or not, as well as the right to withdraw from the study. The lead researcher sought consent from the Head Teacher, the learners, their parents and teachers involved.

The Data Protection Act (1998) guidelines were followed: information gained from the data collection process is kept strictly confidential. Pseudonyms are used in this article when referring to participants. 
While carrying out this research project the first author was an insider researcher and the sets of data were collected in her work place. Her understanding of the support systems in place was helpful as she did not solely have to rely on participants' descriptions or on documentary data to gain an overview of the school's provision. It enabled her to focus on gathering participants' perceptions of the support in place. According to Alderson and Morrow (2011, p5), advantages of being an insider researcher include knowing the specific setting very well, being able to arrange quick access, having an established rapport with participants and being able to put findings into practice.

Although there are some definite advantages to 'researching your own organization while being a complete member' (Coghlan \& Brannick, 2014, p121), it also involved a need for 'thoughtful examination of the ethical implications of the research on individuals' (Coghlan \& Brannick, 2014, p146). Knowing the Welsh school setting well enabled her to acquire an 'understanding in use' rather than 'a reconstructed understanding' (Coghlan \& Brannick, 2014, p121) of the systems in place. However, her roles as a researcher and as the school's Additional Learning Needs Coordinator became 'blurred'. Indeed, 'role duality' (Unluer, 2012, p2) could have led to a loss of objectivity during the research process. 
Another potential disadvantage was regarding the unequal power dynamics between the learners involved and herself (Alderson \& Morrow, 2011). She had to make a point of explaining that her activity in respect of this study was completely separate from her employment (ALNCO) and that agreeing or declining to take part in the study would not impact on the school's treatment of them. Learners selected to take part in the study would have still accessed literacy intervention if they had decided not to take part.

\section{Data collection}

The data collection process was conducted in two stages: this enabled the authors to undertake a data analysis at two specific points and to measure or evaluate progress the learners made.

The following figure illustrates the data collection process during cycle 1. It also provides an overview of the data collection tools used. 


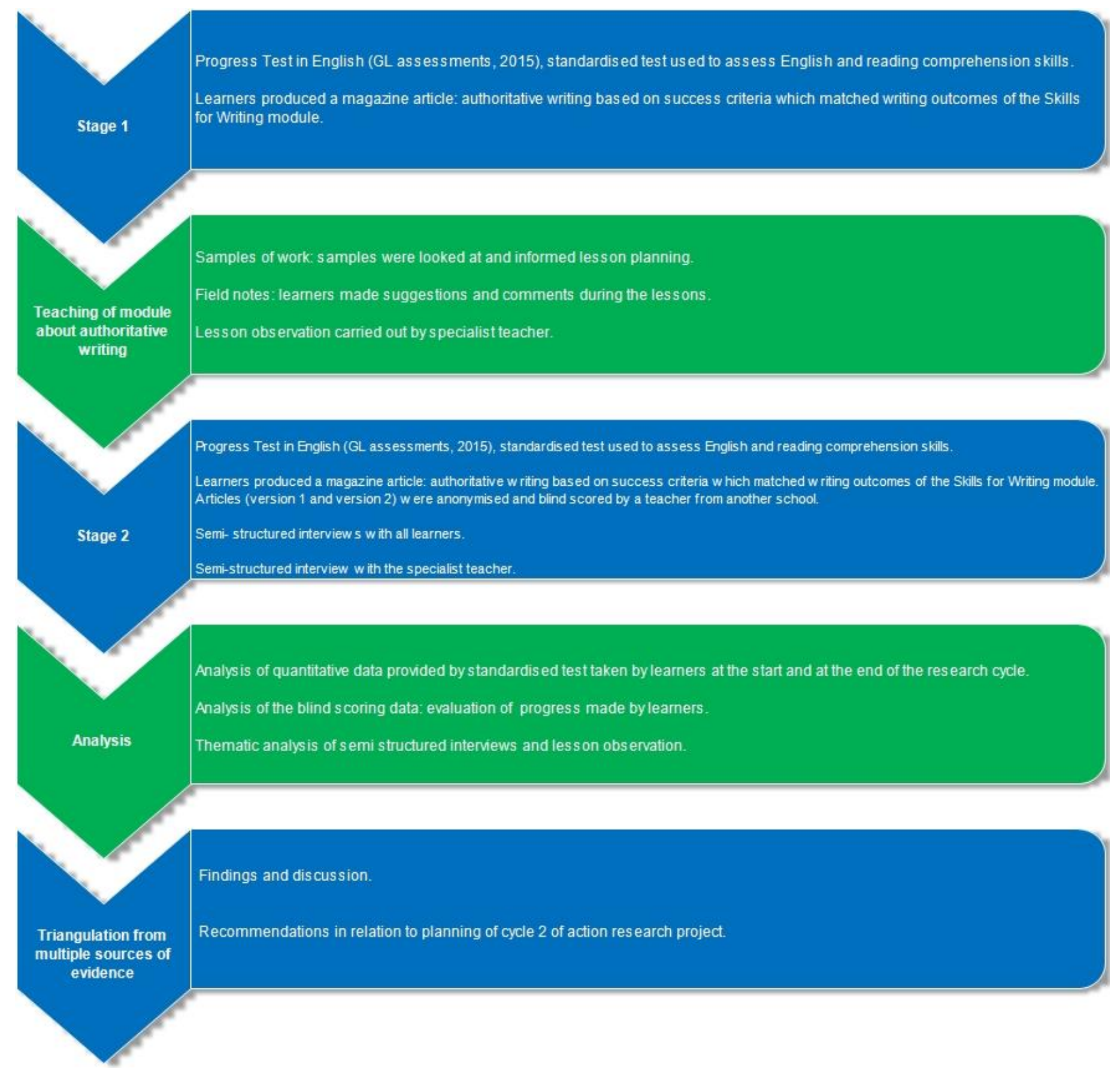

Figure 2 - Cycle 1: data collection stages

The purpose of stage 1 was to provide a baseline against which to monitor and assess learners' progress and the impact of the teaching approach. Stage 2 of the data collection process provided the opportunity to explore in depth the areas of difficulty learners experience in school and 
to gain their opinion on the module they completed. The piece of writing and the standardised test data collected enabled researchers to measure and/or evaluate progress made by learners.

Yin's theory of Convergence of Evidence (Yin, 2009) was applied as it stresses the importance of using multiple sources of evidence to gain an insight into 'the same phenomenon' (Yin, 2009, p117) in order to enhance the quality of the research design.

The documentary data collected during stage 1 fed into the preparation of interview and observation schedules used during stage 2 .

The archival records collected for this project were learners' reports and samples of written work. As with the documentary data, they provided background information about the learners thus giving a wider picture of their academic progress.

Data triangulation was a way to enhance the quality of the research design and to increase understanding of participants' thoughts and learners' progress. 
The analysis of the collected data was completed following Yin's advice and driven by the idea that thematic analyses should refer to all the data collected in order to illustrate the complexity of the findings.

\section{Findings}

The unit of work used is entitled 'Truth is stranger than fiction'. The purpose of this unit is to develop students' ability to analyse non-fiction texts in detail, and to write their own scientific magazine article. There is a particular focus on building understanding of a repertoire of linguistic and grammatical structures and on moving from analysis of patterns in real texts to use of these patterns in their own writing.

\section{Learners' perceptions of support and their personal literacy skills acquisition}

In this section, learners' own definitions and perceptions of their difficulties are described. The section is structured around learners' perspective.

\section{a/ Early years: learning to read and write}

When asked about their primary school experiences, all learners first said: 'I can't remember'. I had to prompt them by asking very specific questions. 
Emily and Jane were reluctant to talk about their primary schools. They both said that they found learning to read and write boring and said their spelling was bad. Their comments were very short; they clearly felt uncomfortable and I decided not to insist.

Mark and Peter responded to my prompts by saying that they could only remember getting 'into trouble':

Mark: I can't remember anything from my old school.

Peter: I kept getting into trouble.

Mark: I just hung around with the wrong people.

They both accessed support sessions in their primary schools but did not comment on learning processes or their feelings with regards to learning to read and write. They chose to focus on their behavioural issues. These are the events they remembered clearly.

Learners' experiences of primary school years were not positive overall. They were unsettled by the question. 


\section{b/ Learners' aspirations}

When learners were asked to talk about their aspirations, 4 out of 5 of them had a clear idea of what they were going to do. They intend on leaving school at the end of year 11 , going to a local college and enrolling on a vocational course. Emily has already identified the course she will need to enrol on:

I want to join the army (...) they have this like military college (...) for that.

Mark was not sure what to do yet. Peter would also like to join the army and Jane would like to become a hairdresser.

Although learners taking part were only 14 years old, they already knew they were not going to aim to join the sixth form or study academic subjects at level 3.

\section{c/ Literacy support in secondary school}

All learners taking part in the study were placed on literacy intervention based on standardised test data. In Wales, Year 7 to 9 learners have to sit national literacy and numeracy tests yearly. In addition, they have to sit literacy and numeracy standardised tests in January so that the school can monitor their progress and put interventions in place if necessary. 
Learners who obtain standardised scores lower than 85 or more than one standard deviation away from the mean (100) are placed on the Additional Learning Needs register. They may be placed on literacy or/and numeracy interventions.

Emily, Jane, Peter and Mark attended literacy support sessions once per week during terms 2 and 3 . They all said they found the sessions helpful:

Interviewer: How do you think it helped?

Emily: We were in a small group and we went over things.

Emily shared her concerns about not being able to access support in year 10, though:

Interviewer: If you could change something about the school, what would it be?

Emily: That year 10s could come in here.

Learners no longer have access to literacy support interventions in years 10 and 11 . They have to focus on their GCSE work and therefore cannot be withdrawn from lessons to attend support sessions. 


\section{d/ Accessing the curriculum in mainstream lessons.}

All learners taking part in the study explained that pace was an issue for them. They felt that teachers were going too fast and that they could not keep up:

Interviewer: Is there anything that teachers could do to make your life easier in class?

Jane: Slow down.

Emily: Like they work us far too fast.

All learners felt left behind as they could not achieve the work set in the time given to them. Mark and Peter added that they kept forgetting instructions. They felt that teachers should repeat instructions regularly to help them maintain their focus.

Peter: They tell me at the start of a lesson, halfway through it, I cannot, like, I have got nothing to write, like I can't think. I start, I just write one thing that she tells me to write and she put, like, she tells me to write other stuff but I just can't remember (...) I am scared because I cannot remember.

Mark suggested teachers should repeat instructions throughout the lesson and come over to help him when he is stuck. 
All learners taking part in the study are in lower ability groups and teachers have to deal with some behavioural issues as well as ensure learners are keeping up with the pace of the lessons. Groups are smaller than the top sets, though, and generally do not exceed 20 learners.

\section{Grammar for Writing strategy: teaching learners to write at length using grammar as scaffolding}

This section summarises learners' and specialist teacher's impressions of the module taught. Although they were encouraged to share their thoughts throughout the teaching sessions, they were asked to answer questions about the content of the sessions at the end of the intervention. Learners' outcomes were analysed using quantitative data combined with teachers' comments on the quality of specific work samples.

\section{a/ Participants' impressions}

Feedback shared by learners was positive overall. They struggled explaining how the explicit teaching of grammar helped them but put some ideas across which were sometimes quite analytical.

Mark and Peter felt that being able to draft and redraft the same piece of extended writing helped them as they 'felt prepared'. They also added that 
learning about the nature and function of words in a sentence helped them when writing:

Peter: Yeah, like using nouns in the right places, I think. And... Mark: Not putting them anywhere.

Peter: Not just run with them. Like, a comma there, like, like you know, that's important.

They were able to use grammatical metalanguage during the interview and were given the opportunity to discuss the functions of words in sentences during lessons.

Emily and Jane's impressions were similar as they also felt that the opportunity to redraft a piece of work was helpful and mentioned that the grammar focus of the lessons helped them with their understanding of words and text:

Interviewer: How do you think it can help you to know what type of words they are?

Emily: We also understand the words, what they mean. (...)

Interviewer: How can it help you write?

Jane: Because we would be able to understand what our sentences meant, too. 
Emily also mentioned that she found using a thesaurus helpful as it gave her 'extra words'. She meant that she often has ideas but would benefit from using reference materials to enrich her writing.

Mark and Peter felt that the sessions helped them construct sentences and therefore increased the accuracy of their syntax. Emily and Jane suggested that grammatical knowledge supported the development of their reading comprehension skills and thus had an impact on the quality of their writing as they felt more comfortable using materials such as a thesaurus.

These comments were echoed by Mrs Jones's observations. Following the lessons she observed, she reported that she felt students were encouraged to think 'outside of their comfort spelling zones but were not left with a negative experience' and that the approach gave them the confidence to be more 'experimental' with language. During the interview, she commented on their concentration levels being problematic at times but had the impression, nevertheless, that continual reinforcement provided by the teacher prevented them from disengaging. 
Learners and Mrs Jones were overall very positive about the sessions and felt that the pedagogical approach was conducive to writing with greater confidence.

b/ Outcomes: what learners achieved

Learners sat a computerised standardised literacy test at the start and at the end of the intervention. The Progress Test in English (GL Assessments, 2015) assesses learners' language skills and reading comprehension skills:

\begin{tabular}{|c|c|c|c|}
\cline { 2 - 4 } \multicolumn{1}{c|}{} & February & July & Analysis \\
\hline $\begin{array}{c}\text { English skills } \\
\text { Spelling }\end{array}$ & $9 \%$ & $9 \%$ & + \\
\hline $\begin{array}{c}\text { English skills } \\
\text { Grammar and } \\
\text { punctuation }\end{array}$ & $27 \%$ & $31 \%$ & $=$ \\
\hline $\begin{array}{c}\text { Reading } \\
\text { comprehension } \\
\text { Narrative }\end{array}$ & $14 \%$ & $14 \%$ & \\
\hline $\begin{array}{c}\text { Reading } \\
\text { comprehension } \\
\text { Non-narrative }\end{array}$ & $15 \%$ & $14 \%$ & \\
\hline
\end{tabular}

Table 1 - Analysis of group scores by subtest: percentage of correct answers 
The group score analysis shows that learners' percentage of correct answers on the grammar and punctuation subtest increased. This suggests that the intervention had had limited impact on other literacy skills. Nevertheless, a majority of learners increased their overall standardised age scores:

\begin{tabular}{|c|c|c|c|}
\cline { 2 - 4 } \multicolumn{1}{c|}{} & February & July & Analysis \\
\hline Emily & 79 & 84 & + \\
\hline Mark & 72 & 73 & + \\
\hline Callum & 79 & 73 & + \\
\hline Peter & 69 & 73 & + \\
\hline Jane & 78 & 73 & - \\
\hline
\end{tabular}

Table 2 - Overall Standardised Age Scores with $90 \%$ confidence bands

The Standard Age Score (SAS) is the most important piece of information derived from PTE. The SAS is based on each learner's raw score which is adjusted for age and placed on a scale that makes a comparison with a nationally representative sample of learners of the same age across the UK. The average score is 100. Although this study's participants' SAS are below the average range, the above data demonstrates that this short grammar-focused intervention helped them develop aspects of their language skills. 
In addition to the standardised test data, samples of work were anonymously assessed by a qualified English teacher who works at a different school. Learners had to produce an extended piece of writing. The unit of work aimed at helping learners develop their authoritative writing skills. Learners had to demonstrate the ability to:

- develop descriptive detail.

- add detail to a description by using expanded noun phrases.

- use semi-colons, disrupted sentences and one-word questions.

- write authoritative non-fiction scientific by selecting from their repertoire of linguistic and grammatical devices.

They had to write a scientific article using the above as success criteria. They wrote their first draft before the start of the intervention and were asked to write their final/second draft at the end of the intervention. The teacher selected to score the work did not teach the children and learners' names were deleted from the writing samples. The teacher did not know which samples were first or second drafts and therefore scored learners' work based on the success criteria provided. The scoring system was based on the New WJEC English language specification, Section B (writing), component 2. The success criteria matched the aims of the intervention as all 5 learners' overall scores were higher on the second writing task. 


\begin{tabular}{|c|c|c|c|c|c|c|c|c|c|c|c|c|c|c|c|}
\hline \multirow[t]{2}{*}{ Learner } & \multicolumn{3}{|c|}{$\begin{array}{l}\text { Ability to develop } \\
\text { descriptive detail }\end{array}$} & \multicolumn{3}{|c|}{$\begin{array}{l}\text { Be able to add detail to a } \\
\text { description by using } \\
\text { expanded noun phrases }\end{array}$} & \multicolumn{3}{|c|}{$\begin{array}{l}\text { Be able to use semi } \\
\text { colons, disrupted } \\
\text { sentences and one } \\
\text { word questions }\end{array}$} & \multicolumn{3}{|c|}{$\begin{array}{c}\text { Be able to write } \\
\text { authoritative non-fiction } \\
\text { scientific by selecting } \\
\text { from your repertoire of } \\
\text { linguistic and } \\
\text { grammatical devices }\end{array}$} & \multicolumn{3}{|c|}{ Overall scores } \\
\hline & $\begin{array}{l}1^{\text {st }} \\
(/ 5)\end{array}$ & $\begin{array}{l}2^{\text {nd }} \\
(/ 5)\end{array}$ & Analysis & $\begin{array}{l}1^{\text {st }} \\
(/ 5)\end{array}$ & $\begin{array}{l}2^{\text {nd }} \\
(/ 5)\end{array}$ & Analysis & $\begin{array}{l}1^{\text {st }} \\
(/ 5)\end{array}$ & $\begin{array}{l}2^{\text {nd }} \\
(/ 5)\end{array}$ & Analysis & $\begin{array}{l}1^{\text {st }} \\
(/ 5)\end{array}$ & $\begin{array}{l}2^{\text {nd }} \\
(/ 5)\end{array}$ & Analysis & $\begin{array}{c}1^{\text {st }} \\
(/ 20)\end{array}$ & $\begin{array}{l}2^{\text {nd }} \\
(/ 20)\end{array}$ & Analysis \\
\hline Jane & 2 & 4 & + & 1 & 2 & + & 0 & 2 & + & 1 & 3 & + & 4 & 11 & + \\
\hline Mark & 2 & 4 & + & 1 & 3 & + & 1 & 0 & $\cdot$ & 2 & 2 & $=$ & 6 & 9 & + \\
\hline Peter & 2 & 3 & + & 1 & 3 & + & 0 & 0 & $=$ & 2 & 2 & $=$ & 5 & 8 & + \\
\hline Callum & 3 & 5 & + & 2 & 4 & + & 0 & 1 & + & 1 & 4 & + & 6 & 14 & + \\
\hline Emily & 3 & 4 & + & 1 & 2 & + & 1 & 1 & $=$ & 2 & 3 & + & 7 & 10 & + \\
\hline
\end{tabular}

Table 3 - Blind scoring: writing an authoritative scientific non-fiction magazine article by selecting from a repertoire of linguistic and grammatical devices 


\section{Making resources and content more accessible to learners}

While on intervention, learners made suggestions regarding ways of adapting the resources. The Specialist Teacher interviewed also made suggestions based on her observations. The lead researcher/teacher also adapted resources and scheme of work based on her own observations.

\section{a/ Learners' suggestions}

Peter suggested I changed the colour of the worksheets. Mark felt that it would also help him:

That helped...that helped me a lot.

Mark also commented on the PowerPoint slides being too busy:

No, it's like, certain slides were like just full of information.

These comments were made during a group discussion while I was teaching the unit. After changing the colour of the worksheets, I also changed the slide backgrounds to yellow (same colour as the worksheets). Emily and Jane could not think of any changes to suggest. They just wished they could have more lessons using this approach:

Interviewer: What should I do differently next time? What changes do you think I could make to the lessons?

Emily: More of them... the lessons. 


\section{b/ Specialist Teacher's suggestions}

When interviewed, Mrs Jones also suggested I adapted materials further. She felt that the print size on the worksheets was too small:

I thought the print was too close together. It perhaps could have been spaced out a bit more.

She also suggested I included a reading comprehension and spelling focus. She felt that the focus on grammar was useful to help them develop their writing skills and that additional emphasis on reading comprehension and spelling skills would have helped learners further:

I felt that there was so much concentration on the grammar that, in some ways, it's a disadvantage because other things that they need to work on, such as their spelling skills to some degree, still were neglected.

\section{c/ Lead researcher/teacher}

The initial adaptations included reducing the amount of content to be taught in each lesson and pre-teaching some of the metalanguage needed.

I also adapted some resources while teaching the unit following comments made by learners regarding the presentation of the work. I will also take 
Mrs Jones's comments into consideration prior to starting the second cycle of this research project. Adding a comprehension element to the unit would help learners feel more comfortable with the language used and guarantee a better grasp of the grammatical elements of the unit.

To conclude, multiple sources of evidence and thematic data analysis enabled me to identify ways of adapting the Skills for Writing materials (Myhill, 2013) so that learners with persistent literacy difficulties can access them.

In the following section, I discuss the main findings in relation to my research question and existing knowledge presented in the theoretical overview (Section 2).

\section{Discussion}

The small sample of learners selected for the study emphasises depth over breadth. The views of five learners clearly cannot be taken as representing views of all learners with dyslexia in all secondary schools in Wales but their experiences and suggestions can help reflect and revise 
the initial plan (Kemmis \& McTaggart, 2005), so that a second research cycle can be undertaken.

\section{Learners' perceptions of support and their personal literacy skills acquisition}

When learners were asked about their primary school years, they mentioned not being able to read and spell accurately (Findings, section 1.a.). They believed that they were poor spellers and subsequently said they did not like having to produce extended pieces of writing. Their difficulties in spelling accuracy and word reading accuracy (BPS, 2005) led them to believe they could not produce quality pieces of writing.

As mentioned in the literature overview, words and grammatical structures are not seen as independent, but rather as mutually dependent. Learners interviewed dislike writing because their spelling is poor. These learners have accessed many phonics-based interventions since their primary school years. Their lack of significant progress in spelling and reading accuracy (they were still identified as needing intervention in year 9) has prevented them from believing that they are able to develop higher order writing skills. As Elliott \& Grigorenko (2014) mentioned, the needs of individual learners fluctuate over time (2014, p138) as reading and writing 
demands increase. The overbearing focus of literacy phonic-based intervention on spelling seems to restrict learners' ambitions by not challenging them enough and not encouraging them to be adventurous with language.

Learners with dyslexia should be encouraged to make connections between word semantics and grammatical structures so that they can then develop higher order literacy skills such as inferential reading comprehension skills as this should help them improve their writing technique (Moreau, 2015).

\section{Participants' perceptions of the Grammar for Writing pedagogical approach.}

As mentioned previously (Theoretical overview, 1.b.), the cognitive demand of spelling directly affects the amount of time that writing takes for learners with dyslexic tendencies and is linked to the quality of writing produced (Sumner et al. 2016). Indeed, learners with dyslexia have difficulties with accurate spelling (Ramus, Marshall, Rosen, \& van der Lely, 2013), and more generally with the composition of written texts (Sumner, Connelly, \& Barnett, 2014). 
According to Sumner et al. (2016), the lower-level transcription process (integrating spelling and handwriting to produce a piece of writing) must become a mechanical skill so that learners can focus on the compositional aspect of writing (Berninger \& Winn, 2006).

This could explain why all learners taking part in the study said they liked attending intervention classes: the pace is slower and the groups are small. With this in mind, when delivering the Skills for Writing unit of work, I often taught at a much slower pace than the scheme of work recommended. Indeed, the processes of planning, spelling and constructing sentences or paragraphs impose a high cognitive demand on poor spellers.

Jones et al.'s findings (2012) demonstrated that the Grammar for Writing intervention had minimal impact on learners whose baseline writing attainment was below average. This strongly suggests that the Grammar for Writing pedagogy may have initially been particularly well-matched to the learning profiles of more able writers (Jones et al. 2012).

However, findings from this study cycle show that adaptations can be made to the schemes of work so that learners with dyslexia can benefit from the explicit and contextualised teaching of grammar. Indeed, 
participants were keen on the pedagogical approach as they were encouraged to make connections between word semantics and grammatical structures in order to improve their writing skills. The use of mentor texts combined with the use of a Thesaurus supported their understanding of how grammatical choices work and offered them a repertoire of possibilities (Myhill et al. 2012). Emily and Jane commented on how the analytical approach helped them understand text. Peter and Mark felt the approach helped them construct sentences. The findings tie in with Myhill et als findings although learners taking part in this study did express the necessity to adapt the resources. Mrs Jones also felt that learners were able to be more experimental with language which demonstrated they were able to take 'control and ownership' (Myhill et al. 2012 , p3) of the articles they composed. The blind scoring data analysis showed there was a distinct improvement in their writing even though the scheme of work had to be slightly adapted to learners' profiles.

\section{Conclusions}

Although Jones et al.'s (2012) findings indicated that the approach only benefited learners whose baseline assessment scores in writing were above average, findings from this study show that the Grammar for Writing pedagogical approach can be adapted to enable learners with persistent 
learning difficulties such as dyslexia to develop their writing skills. Findings highlight the importance of being resourceful when using published materials such as Skills for Writing. Data analysis and reflection resulting from this study cycle will underpin the planning of the second cycle. Following adaptations, learners with persistent literacy difficulties should be able to access that 'repertoire of infinite possibilities which is at the heart of creative, critical shaping of text' (Myhill et al. 2012, p18) despite their spelling and decoding difficulties.

The study demonstrates that participants' learning about writing is enhanced by explicit understanding of grammar. The results of the intervention are important in indicating future directions for research on how to help learners with persistent literacy difficulties develop their writing skills while still having difficulties with the orthographic aspect of language.

Encouraging learners with persistent literacy difficulties to make connections between word semantics and grammatical structures should enable them to develop necessary higher order reading and writing skills in order to cope with the demands of GCSE, AS and A Level examinations. 


\title{
Plan
}

\author{
Reflect \\ Cycle 1 \\ Teach
}

Plan

\author{
Reflect \\ Cycle 2 \\ Teach
}

Figure 1 - Adapted from Kemmis \& McTaggart (2005, p 278) 


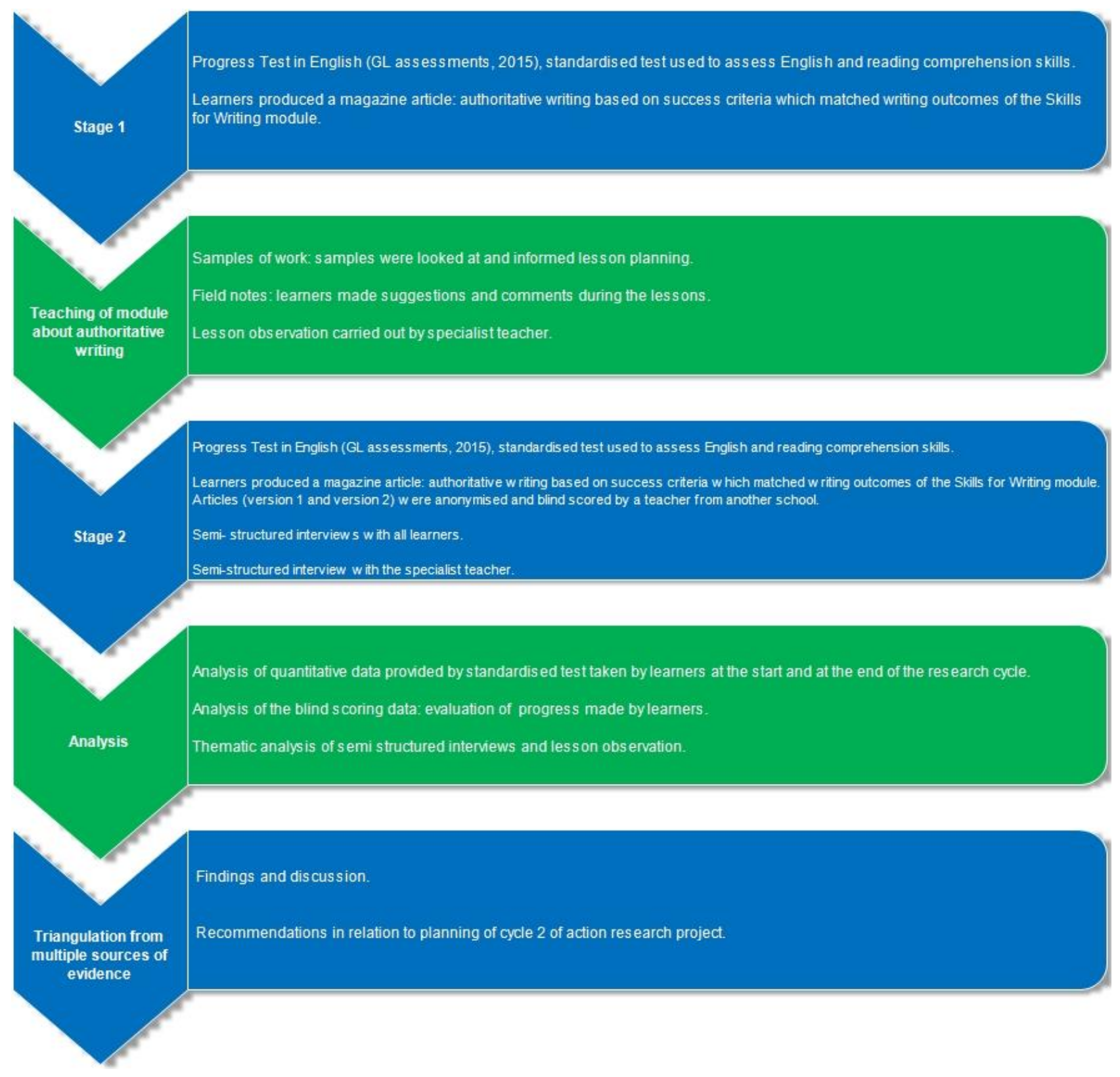

Figure 2 - Cycle 1: data collection stages 


\begin{tabular}{|c|c|c|c|}
\cline { 2 - 4 } \multicolumn{1}{c|}{} & February & July & Analysis \\
\hline $\begin{array}{c}\text { English skills } \\
\text { Spelling }\end{array}$ & $9 \%$ & $9 \%$ & + \\
\hline $\begin{array}{c}\text { English skills } \\
\text { Grammar and } \\
\text { punctuation }\end{array}$ & $27 \%$ & $31 \%$ & $=$ \\
\hline $\begin{array}{c}\text { Reading } \\
\text { comprehension }\end{array}$ & $14 \%$ & $14 \%$ & \\
Narrative & & $14 \%$ & \\
\hline $\begin{array}{c}\text { Reading } \\
\text { comprehension }\end{array}$ & $15 \%$ & & \\
\hline \begin{tabular}{c} 
Non-narrative \\
\hline
\end{tabular}
\end{tabular}

Table 1 - Analysis of group scores by subtest: percentage of correct answers 


\begin{tabular}{|c|c|c|c|}
\cline { 2 - 4 } \multicolumn{1}{c|}{} & February & July & Analysis \\
\hline Emily & 79 & 84 & + \\
\hline Mark & 72 & 73 & + \\
\hline Callum & 79 & 73 & + \\
\hline Peter & 69 & 73 & + \\
\hline Jane & 78 & 73 & - \\
\hline
\end{tabular}

Table 2 - Overall Standardised Age Scores with 90\% confidence bands 


\begin{tabular}{|c|c|c|c|c|c|c|c|c|c|c|c|c|c|c|c|}
\hline \multirow[t]{2}{*}{ Learner } & \multicolumn{3}{|c|}{$\begin{array}{l}\text { Ability to develop } \\
\text { descriptive detail }\end{array}$} & \multicolumn{3}{|c|}{$\begin{array}{l}\text { Be able to add detail to a } \\
\text { description by using } \\
\text { expanded noun phrases }\end{array}$} & \multicolumn{3}{|c|}{$\begin{array}{l}\text { Be able to use semi } \\
\text { colons, disrupted } \\
\text { sentences and one } \\
\text { word questions }\end{array}$} & \multicolumn{3}{|c|}{$\begin{array}{c}\text { Be able to write } \\
\text { authoritative non-fiction } \\
\text { scientific by selecting } \\
\text { from your repertoire of } \\
\text { linguistic and } \\
\text { grammatical devices }\end{array}$} & \multicolumn{3}{|c|}{ Overall scores } \\
\hline & $\begin{array}{l}1^{\text {st }} \\
(/ 5)\end{array}$ & $\begin{array}{l}2^{\text {nd }} \\
(/ 5)\end{array}$ & Analysis & $\begin{array}{l}1^{\text {st }} \\
(/ 5)\end{array}$ & $\begin{array}{l}2^{\text {nd }} \\
(/ 5)\end{array}$ & Analysis & $\begin{array}{l}1^{\text {st }} \\
(/ 5)\end{array}$ & $\begin{array}{l}2^{\text {nd }} \\
(/ 5)\end{array}$ & Analysis & $\begin{array}{l}1^{\text {st }} \\
(/ 5)\end{array}$ & $\begin{array}{l}2^{\text {nd }} \\
(/ 5)\end{array}$ & Analysis & $\begin{array}{c}1^{\text {st }} \\
(/ 20)\end{array}$ & $\begin{array}{c}2^{\text {nd }} \\
(/ 20)\end{array}$ & Analysis \\
\hline Jane & 2 & 4 & + & 1 & 2 & + & 0 & 2 & + & 1 & 3 & + & 4 & 11 & + \\
\hline Mark & 2 & 4 & + & 1 & 3 & + & 1 & 0 & - & 2 & 2 & $=$ & 6 & 9 & + \\
\hline Peter & 2 & 3 & + & 1 & 3 & + & 0 & 0 & $=$ & 2 & 2 & $=$ & 5 & 8 & + \\
\hline Callum & 3 & 5 & + & 2 & 4 & + & 0 & 1 & + & 1 & 4 & + & 6 & 14 & + \\
\hline Emily & 3 & 4 & + & 1 & 2 & + & 1 & 1 & $=$ & 2 & 3 & + & 7 & 10 & + \\
\hline
\end{tabular}

Table 3 - Blind scoring: writing an authoritative scientific non-fiction magazine article by selecting from a repertoire of linguistic and grammatical devices 


\section{References}

ALDERSON, P. \& MORROW, V., 2011. The Ethics of research with children and young people. 2 edn. London, England: Sage publications.

BERNINGER, V.A., 2006. Developmental approach to learning disabilities. In: I. SIEGEL and A. RENNINGER, eds, Handbook of Child Psychology and Practice. 4 edn. New York, United States: John Wiley \& Sons, pp. 420-452.

BERNINGER, V.W. and WINN, W., 2006. Implications of advancements in brain research and technology for writing development, writing instruction, and educational evolution. In: C. MACARTHUR, S. GRAHAM and J. FITZGERALD, eds, Handbook of writing research. New York, United States: Guilford, pp. 96-114.

COGHLAN, D. and BRANNICK, T., 2014. Doing action research in your own organization. 4 edn. London, England: Sage publications.

COHEN, L., MANION, L. and MORRISON, K., 2007. Research methods in education. 6 edn. London and New York: Routledge.

CONNELLY, V., CAMPBELL, S., MACLEAN, M. and BARNES, J., 2006. Contribution of lower order skills to the written composition of older students with and without dyslexia. Developmental Neuropsychology, 29, pp. 175-196.

Data Protection Act 1998 (c.29), London: The Stationery Office. 
DEPARTMENT FOR EDUCATION, 2013. English programmes of study: key stage 3. London: Department for Education.

DEPARTMENT FOR EDUCATION, 2013. English programmes of study: key stage 4, National Curriculum in England. London: Department for Education.

DEPARTMENT FOR EDUCATION, 2013. English programmes of study: key stages 1 and 2, National Curriculum in England. London:

Department for Education.

ELLIOTT, J.G. and GRIGORENKO E.L., 2014. The Dyslexia Debate. New York, United States: Cambridge University Press.

FLYNN, L.J., ZHENG, X. and SWANSON, H.L., 2012. - Instructing struggling older readers: A selective meta-analysis of intervention research. Learning Disabilities Research and Practice, 27, pp. 21-32.

GL ASSESSMENTS, 2015. Progress Test in English. GL Assessments.

GREGG, N., COLEMAN, C., DAVIS, M. and CHALK, J.C., 2007. Timed essay writing: Implications for high-stakes tests. Journal of Learning Disabilities, 40, pp. 306-318.

HALLIDAY, H. and MATTHIESSEN, C., 2014. An Introduction to Functional Grammar. 3 edn. New York, United States: Routledge. 
JONES, S., MYHILL, D. and BAILEY, T., 2013. Grammar for writing? An investigation of the effects of contextualised grammar teaching on students' writing. Reading and Writing An Interdisciplinary Journal, 26(8), pp. 1241-1263.

KEMMIS, S. and MCTAGGART, R., 2005. Participatory Action Research: Communicative Action and the Public Sphere. In: N.K. DENZIN and Y.S. LINCOLN, eds, The SAGE Handbook of Qualitative Research. 3 edn. London, England: SAGE Publications, pp. 271-330.

KOSHY, V., 2010. Action Research for Improving Educational Practice: A Step-By-Step Guide. 2 edn. London, England: Sage Publications.

LOCKE, T., 2005. Writing positions and rhetorical spaces. In: B. DOECKE and G. PARR, eds, Writing=Learning. Wakefield Press, pp. 75--95.

MCCORMACK-COLBERT, A., JONES, S.W. and WARE, J., 2017. Perceptions of support of secondary school learners with dyslexia in France and in Wales: case study analyses. Support for Learning, 32(1), pp. 20-40.

MELLANBY, J.; THEOBALD, K.I. 2014, Education and Learning: an evidence based approach, John Wiley Blackwell, Chichester, England.

MOREAU, A., 2015. The Connection between Reading and Writing in the Writing Center Environment. 470. Allendale, United States: Honors Projects, Grand Valley State University. 
MORKEN, F. and HELLAND, T., 2013. Writing in Dyslexia: Product and Process. Dyslexia, 19(3), pp. 131-148.

MYHILL ET AL., 2013. Skills for Writing. England: Pearson.

MYHILL, D., 2018. Grammar as a meaning-making resource for improving writing. Educational Studies in Language and Literature, 18, pp. 1-21.

MYHILL, D.A., JONES, S.M., LINES, H.E. and WATSON, A., 2012. ReThinking grammar: the impact of embedded grammar teaching on students' writing and students' metalinguistic understanding. Research Papers in Education, 27(2), pp. 139--166.

MYHILL, D.A., LINES, H.E. and WATSON, A., 2011. Making meaning with grammar: a repertoire of possibilities. mETAphor, 2(1), pp. 10.

MYHILL, D.A. and WATSON, A., 2014. The role of grammar in the writing curriculum: a review. Journal of Child Language Teaching and Therapy, 30(1), pp. 41-62.

MYHILL, D., JONES, S., LINES, H. and WATSON, A., 2012. Re-thinking grammar: the impact of embedded grammar teaching on students' writing and students' metalinguistic understanding. Research Papers in Education, 27(2), pp. 139-166. 
RAMUS, F., MARSHALL, C.R., ROSEN, S. and VAN DER LELY, H. K. J., 2013. Phonological deficits in specific language impairment and developmental dyslexia: Towards a multidimensional model. Brain, 136, pp. 630-645.

REID, G., 2011. Dyslexia. 3 edn. London, England: Continuum International Publishing.

THE BRITISH DYSLEXIA ASSOCIATION, 2009-last update, BDA definition of dyslexia. Available:

http://www.bdadyslexia.org.uk/dyslexic/definitions [February 27th, 2018].

The British Educational Research Association 2011, Revised ethical guidelines for educational research.

THE BRITISH PSYCHOLOGICAL SOCIETY, 2005. Dyslexia, literacy and psychological assessment. The British Psychological Society.

THOMAS, G., 2009. How to do your research project. London, England: Sage Publications.

UNLUER, S., 2012. Being an Insider Researcher While Conducting Case Study Research. The Qualitative Report, 17, pp. 1-14.

VIRGINIA, W., BERNINGER, A., KATHLEEN, H., NIELSEN, A. and ROBERT D. ABBOTT,A ELLEN WIJSMAN,B,C and WENDY

RASKINDC, 2008. Writing problems in developmental dyslexia: underrecognised and under-treated. Journal of School Psychology, 46, pp. 121. 
WELSH GOVERNMENT, 2016. Programme of study for English, Key Stages 2-4. Cardiff: Welsh Government.

WELSH GOVERNMENT, 2012. Current literacy and dyslexia provision in Wales. Cardiff, Wales: Welsh Government.

WELSH JOINT EDUCATION COMMITTEE, 2015. GCSE in English Language Specification. Cardiff, Wales: Welsh Joint Education Committee.

YIN, R.K., 2009. Case study research design and methods. 4 edn. London, England: Sage publications. 